\title{
ARE CLINICAL ETHICS CONSULTANTS IN DANGER? AN ANALYSIS OF THE POTENTIAL LEGAL LIABILITY OF INDIVIDUAL CLINICAL ETHICISTS
}

\author{
DAVID N. SONTAG ${ }^{\dagger}$
}

\section{INTRODUCTION}

In September 1999, eighteen-year-old Jesse Gelsinger tragically died while participating in a University of Pennsylvania gene transfer experiment.' The lawsuit that followed this unfortunate incident named as defendants not only the researchers involved but also renowned bioethicist Arthur Caplan. ${ }^{2}$ Although a hospital ethics committee was named in a lawsuit more than ten years earlier, ${ }^{3}$ there had

${ }^{\dagger}$ B.A. 1999, Washington University; M.Bioethics candidate 2003, University of Pennsylvania Medical School; J.D. candidate 2003, University of Pennsylvania Law School. I thank my wife, Sarah, for her constant love and support, but especially for being so patient during the writing and editing of this Comment. I would also like to thank Colin Diver, Anita Allen-Castellitto, Art Caplan, David Magnus, and Paul Root Wolpe for their insightful comments and recommendations. Finally, I am extremely grateful to Jodi Rosensaft, Michael Bacchus, Aiesha Hudson, and the rest of my colleagues on the University of Pennsylvania Law Review for their hard work and dedication during the editing process.

'Alex Lapinski, In Aftermath of Gelsinger's Death, Tighter Rules for Tests, DAlLY PENNSYLVANIAN, Nov. 6, 2001, http://www.dailypennsylvanian.com/vnews/display.v/ ART $/ 2001 / 11 / 06 / 3$ be 7 b02f2e4l2?in_archive $=1$. This type of experiment is more commonly known as "gene therapy." There has been much debate about the appropriateness of this term, however, because it implies that the "experiment" or "research" will actually have a beneficial effect on the subject. 'Confusion of "therapy" for "research" is a serious issue in debates about informed consent in research, and bioethics generally. See Larry R. Churchill et al., Genetic Research as Therapy: Implications of "Gene Therapy" for Informed Consent, 26 J.L. MED. \& ETHICs 38, 45 (1998) (noting a "persistent failure to distinguish clearly between research and therapy in medical science"); $M$. Therese Lysaught, Commentary: Reconstming Genetic Research as Research, 26 J.L. MED. \& ETHICS 48, 48 (1998) (attempting to "contextualize further Churchill et al.'s arguments in the experience of [the National Institutes of Health's Recombinant DNA Advisory Committee] and the history of gene transfer research").

2 Complaint at 6-7, Gelsinger v. Univ. of Pa., No. 001885 (Pa. Ct. Com. Pl. Phila. filed Sept. 18, 2000) (on file with author).

Elizabeth Bouvia named an ethics committee (both as a whole and its members individually) as a defendant after physicians, supposedly acting under the committee's direction, inserted a nasogastric tube in Bouvia against her wishes. Bouvia v. Superior Court, 225 Cal. Rptr. 297, 297 (Cal. Ct. App. 1986); see also JUDITH WiLSON Ross ET AL., HeAlTh CARE Ethics COMmitTeES: ThE NeXt Generation 135 (1993) (examining 
not been any other such instances until the Gelsinger case in 2000. However, since the Gelsinger lawsuit was filed (it was ultimately settled out of court), at least one more lawsuit has named bioethicists as defendants. ${ }^{4}$ Accordingly, bioethicists have begun to worry about the possibility of being found liable for the advice they give. ${ }^{5}$ Due to the close contact with traditional decision makers in the clinical context (i.e., patients and physicians), bioethicists who participate in individual case consultations have become especially concerned about potential exposure to liability for their advice under tort law. ${ }^{6}$ Hence, the potential liability of these "clinical ethicists" has become a hot topic in legal, medical, bioethical, and sociological circles.

Bouvia's case); Andrew L. Merritt, The Tort Liability of Hospital Ethics Committees, $60 \mathrm{~S}$. CAL. L. REV. 1239, 1250-52 (1987) (discussing the facts of Bouvia to demonstrate "that ethics committees are involved in decisions that can lead to litigation"). After Bouvia was granted an injunction to have the tube removed, Bouvia, 225 Cal. Rptr. at 307, she dropped the suit. "Although the plaintiff in that case, Elizabeth Bouvia, never pursued her action against the ethics committee to final decision or judgment, the mere filing of the case sent shudders through the bioethics community." ROSS ET AL., supra, at 135.

${ }^{4}$ Complaint, Robertson v. McGee, No. 01CV00G0H(M) (N.D. Okla. filed 2001), http://www.sskrplaw.com/gene/robertson/complaint.html. The bioethicists named in this suit were all members of the Institutional Review Board (IRB) that reviewed and approved the research protocol in the case. The complaint alleged that the IRB defendants "did not properly perform their functions in that they failed to examine the design of the protocol, ... review the operation of the Trial, assure the protection of the participants, ... ensure proper reporting, and make certain that the Trial comported with ethical standards." Id.

"5his general concern from the bioethics community was the driving force behind the organization of a Symposium, co-sponsored by the Center for Bioethics and the School of Law at the University of Pennsylvania, entitled The Legal Duties of the Bioethicist. In fact, Arthur Caplan was one of the organizers of the symposium. (Anita L. Allen-Castellitto was the other organizer.) The Symposium occurred on April 11, 2001.

${ }^{6}$ It is important to note that there has been no judicial pronouncement regarding the liability of ethics committees or individual clinical ethicists. In fact, the only known case brought against a bioethicist in the clinical context is that brought by Bouvia, but that case was dropped. Ross ET AL., supra note 3, at 135 . The other cases previously mentioned, Gelsinger and Robertson, involved bioethicists in the research context. See supra note 2 and accompanying text (discussing the Gelsinger lawsuit); supra note 4 (summarizing the Robertson lawsuit). They also settled before final decisions could be reached in the cases. The potential legal liability of research bioethicists is beyond the scope of this paper. These cases are mentioned only to illustrate why bioethicists in every context have begun to be concemed about exposure to legal liability.

In this Comment, the terms "clinical ethicist" and "ethics consultant" will be used interchangeably for the sake of consistency with the existing literature discussing these individuals. However, John C. Fletcher argues that these are not synonymous. He writes, "The role of those who specialize in nurturing the activity of clinical ethics is better understood as that of a 'consultant in clinical ethics,' than of an 'ethicist.' This term avoids the implication of elitism or domination of the process of clinical ethics." 
Hospital ethics committees have been the focus of many discussions ever since the New Jersey Supreme Court decided In re Quinlan. ${ }^{8}$ In the years since that decision, however, ethics consultation has ceased to be performed solely by committees. In fact, consultations performed by individual clinical ethicists are becoming increasingly popular. ${ }^{9}$ One reason for this may be the functional aspects of the increasing demand for ethics consultations ${ }^{10}$ - ethics committees are difficult to call to action on a moment's notice ${ }^{11}$ and they can only handle one case at a time; whereas individual ethicists are easy to contact, and multiple individual ethicists can work on different cases simultaneously. ${ }^{12}$ Another reason is that " $[\mathrm{h}]$ ealth care professionals... probably are more likely to ask for help from an ethics consultant than from an ethics committee" because the health care professionals are familiar, and therefore comfortable, with requesting consultations from individual medical specialists. ${ }^{13}$ Finally, the growing popularity of consultations with individual ethicists may be attributed simply to the belief that "[c]onsultations are almost always better when performed one-on-one." 14

Janet Fleetwood and Stephanie Unger are quick to note, however, that the competing models of consultation by individual and consultation by committee both have "advantages and shortcomings." 15 Re-

John C. Fletcher, The Bioethics Movement and Hospital Ethics Committees, 50 MD. L. REv. $859,860 \mathrm{n} .4$ (1991). For further discussion of why an "implication of elitism" or perceived "domination of the process of clinical ethics" is problematic, see infra Part II.

${ }^{8} 355$ A.2d 647 (N.J. 1976); see infra notes 180-85 and accompanying text (discussing Quinlan).

${ }^{9}$ See infra note 16 and accompanying text (explaining that the individual ethics consultant is replacing the ethics committee as the primary provider of ethics consultations).

${ }^{10}$ See Mark P. Aulisio et al., Health Care Ethics Consultation: Nature, Goals, and Competencies, 133 ANNALS INTERNAL MED. 59, 59 (2000) (noting "the growing prevalence of ethics consultation").

"See Bowen Hosford, Broethics Committees: The Health CARE Provider's GuIDE 98 (1986) ("Committees are cumbersome. It takes time to assemble a group.").

${ }^{12}$ See ROSS ET AL., supra note 3, at 98 ("A clinical ethics consultant can provide timely, efficient, and consistent responses to ethical problems in patient care.").

${ }^{13}$ Id.

${ }^{14}$ George J. Annas, Ethics Committees: From Ethical Comfort to Ethical Cover, HASTINGS CENTER REP., May-June 1991, at 18, 19.

${ }^{15}$ Janet Fleetwood \& Stephanie S. Unger, Institutional Ethics Commiltees and the Shield of Immunity, 120 ANNALS INTERNAL MED. 320, 321 (1994). For discussions of these advantages and shortcomings, see Judith Wilson Ross, Case Consultation: The Committee or the Clinical Consullant?, 5 HOSP. ETHICS COMMITTEE F. 289; Mark Siegler \& Peter A. Singer, Clinical Ethics Consultations: Godsend or “God Squad?, 85 AM. J. MED. 759 (1988). 
gardless of whatever shortcomings consultations by individual clinical ethicists may have, "the ethics consultant is replacing the ethics committee in [consultations]." 16 For this reason, this Comment will focus on analyzing the potential legal liability of individual clinical ethicists.

Since committee discussion has been the major format for ethics consultations for longer than individual interaction, committees have been the focus of many more academic inquiries, which include such issues as who should be members, what role they should play in consultations, and what their potential exposure is to legal liability (both as a whole, and their members individually). In spite of the differences between consultations performed by ethics committees and those carried out by individual clinical ethicists, these discussions of ethics committees can be very useful when considering the individual ethicist. In fact, there are many instances in which the previous analyses are directly applicable to the discussion of individual ethicists. ${ }^{17}$

In Part I of this Comment, I discuss the variety of tasks individual clinical ethicists may perform, explain the focus on ethics consultations, and provide an example of a situation in which a clinical ethics consultation might prove to be useful. In Part II, I provide a definition of "clinical ethics," refute objections that ethics consultation is unnecessary or undesirable, and present two opposing views of what clinical ethicists' role should be in case consultations. In Part III, I focus on why legal liability has only recently become an issue for clinical ethicists. Finally, in Part IV, I analyze specific types of liability to which a clinical ethicist could be exposed for her involvement in an individual case consultation. This Part ends with my conclusion that clinical ethicists' role in case consultations should be largely that of mediators, or facilitators of moral consensus, in order to limit their exposure to potential liability.

\section{WHAT DO CLINICAL ETHICISTS DO?}

Clinical ethicists generally perform three main functions. First, they are often asked to provide ethical input for the development and implementation of patient care guidelines and policies for various

\footnotetext{
${ }^{16}$ Annas, supra note 14, at 19; see also Terrence F. Ackerman, Conceptualizing the Role of the Ethics Consultant: Some Theoretical Issues, in ETHICS CONSULTATION IN HEALTH CARE 37, 37 (John C. Fletcher et al. eds., 1989) ("Evidence suggests that [the individual ethicist providing consultation to an attending physician regarding the care of a particular patient] is the most frequently utilized form of ethics consultation.").

${ }^{17}$ In these instances, I will simply cite to or quote those prior arguments, even though they refer specifically to ethics committees.
} 
health care institutions. ${ }^{18}$ Second, clinical ethicists are often asked to educate health care professionals (e.g., physicians, nurses, etc.) within an institution about ethical concerns associated with the care of patients. ${ }^{19}$ Third, the most often discussed function clinical ethicists are asked to perform is individual case consultation, in response to either a patient's or a physician's request. ${ }^{20}$

Judith Hendrick lists three other functions that clinical ethicists are asked to perform: "reducing litigation, helping to protect healthcare professionals legally by making them aware of any applicable law, and providing a forum for discussion of legal issues." ${ }^{21}$ Other authors do not list these three tasks, a phenomenon that could be attributed to the refusal of clinical ethicists and health care institutions to identify publicly any watchdog-type activities as the responsibility of the clinical ethicist. It could also be due to the lack of consensus by academics and participants (e.g., health care institutions, clinical ethicists, physicians, patients) concerning whether or not clinical ethicists should be performing these functions. For example, John Fletcher recognizes that ethics consultations help to keep physicians' fear of liability from interfering with good medical practice because they help to reduce the number of "unnecessary" malpractice suits. ${ }^{22}$ However, he shares the view that an ethics committee should not become a forum for risk management. ${ }^{23}$ When considered simultaneously, Fletcher's statements could be interpreted to mean that although ethics consultations may help reduce litigation, this should not be the designated function or the goal of the clinical ethicist. Many involved

${ }^{18}$ John C. Fletcher \& Dianne E. Hoffmann, Ethics Commiltees: Time to Experiment with Standards, 120 ANNALS INTERNAL MED. 335, 336 (1994); Anne-Marie Slowther \& Tony Hope, Clinical Ethics Committees: They Can Change Clinical Practice but Need Evaluation, 321 BRIT. MED. J. 649, 650 (2000). 650.

19 Fletcher \& Hoffmann, supra note 18, at 336; Slowther \& Hope, supra note 18, at

${ }^{20}$ Fletcher \& Hoffmann, supra note 18, at 336; Slowther \& Hope, supra note 18, at 649. The term "patient" will generally be used to refer not only to the patient herself, but also to the patient's family or any other designated guardian for the patient in instances where the patient is not in a position to make a decision for herself. Similarly, the term "physician" will generally include any health care provider who would have to make a treatment decision, such as a nurse.

${ }^{21}$ Judith Hendrick, Legal Aspects of Clinical Ethics Committees, 27 J. MED. ETHICs i50, i51 (2001).

${ }_{22}$ Fletcher, supra note 7 , at 879 . Fletcher defines "unnecessary" malpractice suits as "suits that arise because ethical problems left unresolved at the bedside smolder and then flame into disputes." Id.

${ }^{23}$ See Fletcher \& Hoffmann, supra note 18, at 336 ("An ethics committee that becomes a forum for risk management has abdicated its mission."). 
parties are concerned that if clinical ethicists are asked to perform these tasks, "legal" will come to be equated with "ethical," even though the two are not necessarily synonymous, ${ }^{24}$ and that clinical ethicists will abandon consideration of the latter for the former.

This Comment will focus on the clinical ethicist's role as a consultant for individual cases because it is the most likely to expose the ethics consultant to potential liability; the clinical ethicists' roles as educator and policymaker are incredibly unlikely to produce instances in which they could be held liable for the advice they give.

\section{A. What Would Constitute an "Ethics Consultation"?}

It is important to understand that " $[\mathrm{e}]$ thics consultation is a genus which encompasses a variety of species." Fletcher provides a minimalist definition of "ethics consultation": "a meeting, or series of meetings on a continuum from 'informal' to 'formal,' between person(s) in need of help with an ethical problem and person(s) appointed to provide such help." ${ }^{26}$ From this, it is possible to define "clinical ethics consultation" in the following manner: a meeting between a patient, her physician, and an ethics consultant, in which the ethicist assists the patient and physician in resolving their ethical disagreement. $^{27}$ A more specific, detailed definition would not be general enough to encompass the significant variation among competing conceptions of exactly how the ethics consultation should be performed.

Instead of discussing these divergent views in the abstract, the following subsection introduces an example of a situation in which an

${ }^{24}$ For further discussion of this issue, see infra Part III.

${ }^{25}$ Ackerman, supra note 16, at 37; see also David C. Thomasma, Ethics Consultation Rules: A Comment on George J. Agich, AM. J. BIOETHICS, Fall 2001, at 46, 46 ("[E]thics consultation is a complex form of human interaction, of interpretation, of balance between values and identity of patients, families, professionals, institutions, and culture.").

${ }^{26}$ John C. Fletcher, Standards for Evaluation of Ethics Consultation, in ETHICS CONSUltATION IN HEALTH CARE, supra note 16, at 173, 175.

${ }^{27}$ An ethics consultation could be requested even though there is not a disagreement between the patient and the physician. A moral dilemma can occur within a single person, as well. See John C. Fletcher et al., Clinical Ethics: History, Content, and Resources, in INTRODUCTION TO CLINICAL ETHICS 3, 11 (John C. Fletcher et al, eds., 2d ed. 1997). However, situations in which the patient would be unsure of what option to choose without knowing what the physician thinks is best are rare. Therefore, the overwhelming majority of requests for ethics consultations will involve either an actual or a potential disagreement between patient and physician. See also infra note 57 (explaining that most consultation requests concern the resolution of conflict). 
ethics consultation might prove helpful. It also presents the different approaches a clinical ethics consultant could take in assisting the patient and physician to resolve the dilemma.

\section{B. An Illustrative Example}

A fifty-seven-year-old woman is admitted to the hospital because of a fractured hip. During her stay in the hospital, the woman's physician discovers that she has stage $1 \mathrm{~A}$ carcinoma of the cervix. Luckily, because the cancer is caught early, it is almost certainly curable by a hysterectomy. However, the patient refuses to have the surgery. Based on the patient's "unreasonable" refusal to undergo surgery, the treating physician believes that the woman is not mentally competent to make decisions regarding her own care. ${ }^{29}$ The physician requests a psychiatric consultation to confirm this belief. The psychiatric consultant, however, does not agree that the patient is mentally incompetent. At this point, the physician has three options. She can (1) seek a court order to allow her to perform the surgery against the patient's will, and probably save her life; (2) accept the competent patient's autonomous decision, and discharge her "Against Medical Advice"; or (3) attempt to resolve the disagreement between herself and the patient. Clearly, option three is preferable. In such a case, an ethics consultation might help resolve the disagreement.

If a clinical ethicist were called to discuss the situation with the patient and physician, the consultation could take a number of forms. Without commenting on what role the ethicist should play, which will be discussed in Part II, the following are examples of how the consultation could go.

First, a clinical ethicist could try in a neutral manner to elucidate the reasoning behind the patient's and physician's respective convictions, with the ultimate goal being a true consensus between the dis-

${ }^{28}$ The following example is based on an actual, more detailed case, which was altered slightly for simplicity. For the full story, see Ruth Faden \& Alan Faden, False Belief and the Refusal of Medical Treatment, 3 J. MED. ETHICs 130, 133-36 (1977), quoted in TOM L. BEAUChamp \& James F. ChILdRESS, PRinciples of BIOMEDICAL ETHICS 92 (5th ed. 2001).

${ }_{29}$ According to David Magnus, Director of Graduate Studies for the Center of Bioethics at the University of Pennsylvania, "if your only reason for questioning the patient's competency is that the patient does not agree with you, then you have misframed the issue." Interview with David Magnus, Director of Graduate Studies, University of Pennsylvania Center for Bioethics, in Philadelphia, Pa. (Mar. 26, 2002). This is a clear sign that an ethics consultation probably would be helpful because it could help elucidate the true dilemma. 
agreeing parties. Second, the ethicist, after hearing each participant's explanations, could tell the patient and physician what she thinks should be done in the situation. This recommendation would not be binding on the parties. Third, the ethicist could take the previous option a step further; instead of simply issuing a nonbinding recommendation and providing an explanation for that recommendation, the ethics consultant could actively try to convince the party opposed to the proposal that it is the only ethically acceptable option. For example, the clinical ethicist could stress the patient's right to make an autonomous decision to refuse treatment, and then attempt to convince the physician that the only ethical option is respecting the patient's wishes. Or, the ethicist could act as a physician-advocate, working with the physician to convince the patient that her position is ethically unacceptable. In either case, a "consensus" might be reached, though not through discussion and clarification, but through coercion. Fourth, in rare circumstances, the ethicist could issue a binding decision about what should be done.

\section{What Should Be the Glinical Ethicist's Role in CaSE CONSUlTATIONS? $?^{30}$}

Judith Ahronheim, Jonathan Moreno, and Connie Zuckerman note that "there is no single, universally accepted definition of clinical ethics." However, based on the definitions presented by leading figures in the field of bioethics, Ahronheim, Moreno, and Zuckerman have formulated their own definition of clinical ethics:

[T] he systematic identification, analysis, and resolution of ethical problems associated with the care of particular patients. Its goals include protecting the rights and interests of patients, assisting clinicians in ethical decision making, and encouraging cooperative relationships among patients and those close to patients, clinicians, and health care institutions.

\footnotetext{
${ }^{30}$ David Casarett, Frona Daskal, and John Lantos explain that even though the language of this discussion is often phrased in terms of the ethics consultant's "role," the fundamental question is about the ethics consultant's "moral authority." David J. Casarett et al., Expert in Ethics? The Authority of the Clinical Ethicist, HASTINGS CENTER REP., Nov.-Dec. 1998, at 6, 6. For the sake of consistency with existing literature, I will structure the discussion in terms of the clinical ethicist's role.

${ }^{31}$ Judith C. AHRONHEIM, JONATHAN D. MORENo \& CONNIE ZUCKERMAN, ETHICS in Clinical Practice 1 (2d ed. 2000).

${ }^{32}$ Id. at 2. Ahronheim, Moreno, and Zuckerman based their definition on the following authorities: AlberT R. JONSEN ET AL., ClinicAl ETHICS 1 (3d ed. 1992); Fletcher, supra note 7, at 859 n.4; John La Puma, Clinical Ethics, Mission and Vision:
} 
Considering the many goals that can be ascribed to the practice of clinical ethics, it should come as no surprise that exactly what the clinical ethicist's role should be in case consultations is hotly debated. ${ }^{33}$ This debate is dependent on the assumption that the involvement of clinical ethicists in individual cases is desirable.

\section{A. Is the Involvement of Clinical Ethicists in Individual Cases Even Desirable?}

Many authors argue that the involvement of clinical ethicists in individual cases is not desirable. Frank (Yeruham) Leavitt is one such author. Leavitt cites three problems with consulting a clinical ethicist about the appropriate treatment decision in specific cases. ${ }^{3.4}$ First, Leavitt is concerned with the possibility of a conflict of interest because clinical ethicists may be inclined to serve the interests of the institutions that employ them rather than the interests of the patients. Second, Leavitt fears that physicians will shift the responsibility for hard decisions to the clinical ethicists. ${ }^{36}$ Third, Leavitt thinks the consultation of clinical ethicists "can be an excuse for ward staff not to read biomedical ethics literature themselves and not to think deeply about bioethical questions."

Scot Yoder would categorize Leavitt's main arguments against clinical ethics consultation as "moral arguments" because they "do not question the possibility of ethics expertise so much as the wisdom or appropriateness of recognizing people as ethics experts." ${ }^{38}$ Another

Practical Wisdom in Health Care, 35 HosP. \& HeAlth SERvices Admin. 321, 321-26 (1990).

${ }^{33}$ For example, nearly half of an entire issue of The American Joumal of Bioethics was devoted to discussion of "The Question of Method in Ethics Consultation." AM. J. BIOETHICS, Fall 2001, at 31, 31-59.

${ }^{34}$ Frank (Yeruham) Leavitt, Letter to the Editor, Hospital Ethics Committees May Discourage Staff from Making Own Decisions, 321 BRIT. MED. J. 1414, 1414 (2000). Leavitt believes the clinical ethicist's function should be mainly educational, "helping present and future doctors and nurses to learn to think deeply, systematically[,] and for themselves about life, death, and their ethics." Id.

${ }^{35}$ See id. ("[E]thicists ... who are hired or appointed by hospitals, national health services, or sick fund managements may naturally be selected to serve the interests of management.").

${ }_{37}^{36} I d$.

${ }^{38}$ Scot D. Yoder, Experts in Ethics? The Nature of Ethical Expertise, HASTINGS CENTER REP., Nov.-Dec. 1998, at 11, 12. Yoder explains that moral arguments "typically make the claim either that ethics expertise is inconsistent with the tenets of liberal democracy or that where ethical matters are concerned it would be dangerous to invest anyone with the power and authority granted to an 'expert' or 'professional." Id. 
"moral argument" against the necessity of clinical ethics consultations would be that "men or women of conscience who thoughtfully apply themselves to the moral problems faced in professional practice can arrive at morally correct decisions. ... . [G]ood people generally produce good results."

Yoder also recognizes another type of argument against clinical ethics consultations, which he refers to as "conceptual/empirical arguments." These arguments raise questions about the possibility or existence of ethics expertise, often making one of several claims: "that ethics is not the sort of thing about which it is possible to have expertise, that the methods employed by the so-called experts are fundamentally flawed, or that the empirical evidence does not support the claim of expertise." ${ }^{\prime 1}$ Most critics of consulting clinical ethicists make both moral and conceptual/empirical arguments. Both types of arguments are based on false assumptions and, hence, fail.

First, all three of Leavitt's arguments assume that the clinical ethicist in a case consultation "deliver[s] 'right answers' to moral questions." However, as I will later argue, ethics consultants do not (or, at least, should not) claim to know the best outcome. ${ }^{43}$ Rather, they should facilitate consensus between the patient and the physician. ${ }^{44}$ Hence, Leavitt's objections to ethics consultation are critically flawed.

Specifically, there can be no conflict of interest between serving the institution and serving the patient because the clinical ethicist is not really "serving" either party. Instead, the ethics consultant is guiding the patient and physician toward a common goal-moral consensus-which is simultaneously in both of their interests. ${ }^{45}$ Also, physicians cannot shift the responsibility for hard decisions to the clinical ethicist because the clinical ethicist will not assume that responsibility. In consensus building, the ultimate responsibility of reaching a mutually acceptable conclusion belongs to the active participants (patient and physician), rather than the guide (ethicist). Finally, the process

${ }^{39}$ Terrence F. Ackerman, The Role of an Ethicist in Health Care, in HEALTH CARE ETHICs 308, 309 (Gary R. Anderson \& Valerie A. Glesnes-Anderson eds., 1987).

4oder, supra note 38, at 12.

${ }^{41}$ Id.

42 Ackerman, supra note 39 , at 318 .

Infra Part II.B.

${ }^{44}$ Infra Part II.B.

45. See Casarett et al., supra note 30, at 7-9 (discussing the role of clinical ethicists as facilitating consensus). 
of consensus building requires the physician's input and thereby forces the physician to think deeply about bioethical questions.

Second, the objection that "morally conscientious persons are thoroughly capable of resolving moral problems encountered in professional practice without the assistance of specialists in ethics" ${ }^{\text {"46 }}$ assumes that people with "strong moral character" possess the tools necessary "to assure satisfactory resolution of moral problems in clinical practice." ${ }^{47}$ In reality, though, clarification of values, identification of alternative solutions, and assessment of their moral consequences ${ }^{48}$ require skills that most physicians and patients do not have. ${ }^{49}$ This is apparent from the heated debate about what skills are necessary to be an effective clinical ethics consultant. ${ }^{50}$ It was also made apparent by a task force formed by the Society for Health and Human Values and the Society for Bioethics Consultation.

This task force composed a list of the core competencies clinical ethics consultants should have." The Task Force Report recognized that " $[t]$ he supplemental education or training that any person may need to acquire a particular competency will be contingent on ... [her] professional background, experience, and personal qualities, and ... the capacity in which [she] do[es] ethics consultation." ${ }^{452}$ This implies that regardless of what level or type of additional training one might need to "acquire a particular competency," some additional education will be required for anyone wishing to be a clinical ethics consultant. Therefore, one can infer that no physician would possess all of the necessary skills, knowledge, and character traits to ensure an ethically appropriate resolution to every morally problematic case she encounters.

${ }^{46}$ Ackerman, supra note 39 , at 319.

${ }^{47}$ Id.

48 See id. (describing the process by which moral problems are resolved).

49 See Ackerman, supra note 16, at 46 (concluding that "the consensus [the goal of ethics consultation] must be molded by persons who are thoroughly familiar with relevant values, facts, options, and the consequences of their implementation").

5ee infra notes 150-57 and text accompanying notes 152-57 (discussing various opinions about what skills one should possess to be a clinical ethicist).

5I SOC'Y FOR HEALTH \& HuMAN VALUES-SOC'Y FOR BIOETHICS CONSUlitations, Core Competencies for Health CaRe Ethics Consultants: The REport of THE AMERICAN SOCIETY FOR BIOETHICS AND HUMANITIES 11-21 (1998) [hereinafter TASK FORCE REPORT].

${ }_{52}$ Aulisio et al., supra note 10 , at 64 (summarizing the content of the Task Force Report). 
Finally, the objection that "ethics is not the sort of thing about which it is possible to have expertise ${ }^{\$ 5.3}$ misinterprets the very nature of ethics consultation. Successful ethics consultation is not dependent on a "systematic knowledge of right and wrong," cal consultation is dependent on a systematic knowledge of facts and principles that can be applied to the case at hand to treat the patient. ${ }^{55}$ Rather, clinical ethicists rely on "a variety of conceptual resources in providing clinical assistance" ${ }^{, 50}$ in order to facilitate a consensus between patients and physicians. A definitive conception of what is right and wrong is not necessary to ensure that the patient and physician come to a common understanding of what are ethically permissible solutions to the problem at hand.

It seems clear, therefore, that clinical ethics consultations can be quite useful when there are difficult issues to resolve-most notably, disagreement between the physician and the patient regarding what further action to take. ${ }^{.7}$

53 Yoder, supra note 38 , at 12.

${ }^{54}$ Ackerman, supra note 39, at 318.

55 See id. at 308-09 (stating that clinical medical experts apply a "complex body of knowledge" consisting of "widely accepted bodies of facts \& principles" to make treatment decisions). Critics that make this objection "seriously overestimate[] the degree of systemization achieved in our scientific knowledge of medical practice." Id. at 318 . For example, there are a great number of illnesses for which patients receive many different treatments, depending not on income or what type of specialist they see, but rather on what part of the country or in what hospital they are located. For a discussion of variations in medical practice, see John E. Wennberg, Dealing with Medical Practice Variations: A Proposal for Action, 3 HEALTH AFF. 6 (1984). See also Mark R. Chassin et al., Variations in the Use of Medical and Surgical Serrices by the Medicare Population, 314 NEW ENG. J. MED. 285, 287 (1986) (comparing the usage rates of certain procedures by patients sixty-five years old or older); John E. Wennberg et al., Professional Uncertainty and the Problem of Supplier-Induced Demand, 16 SOC. SCI. MED. 811, 812-17 (1982) (describing variation in utilization with a specific study of surgical practices).

Ackerman, supra note 39 , at 318 .

57 See Robert D. Orr, Methods of Conflict Resolution at the Bedside, AM. J. BIOETHICS, Fall 2001, at 45, 45 ("It has been my experience over the nearly [twenty] years I have been doing bedside ethics consultations ... that the majority of ethics consultations are requested for assistance in the resolution of conflict about further treatment."). In fact, a recent study of hospital ethics committees revealed that the majority of consultation time is spent on three issues concerning treatment: "patient autonomy; the capacity of patients to make their own health decisions; and ... miscommunication among staff, clinicians and patients about the meaning and goals of treatment." Glenn McGee, Arthur L. Caplan, Joshua P. Spanogle \& David A. Asch, A National Study of Ethics Committees, AM. J. BiofTHICs, Fall 2001, at 60, 63. 


\section{B. Two Views of What the Clinical Ethicist's Role Should Be in Case Consultations}

The heart of the debate is what exactly the clinical ethicist's role should be in case consultations. ${ }^{58}$ Moreno identifies two models of clinical ethics consultation. ${ }^{59}$ The first, and less common, Moreno labels the "hard" model. In this model, the ethics consultant acts like a traditional clinician; she undertakes independent investigation of the patient's medical and moral situation, which includes an examination and interview of the patient and family, and then issues a recommendation about what treatment she thinks is ethically appropriate. ${ }^{60}$ The Judicial Council of the American Medical Association seems to prefer the "hard" model of ethics consultation, but it makes clear that the recommendations should not be, nor be considered, binding:

Ethics committees in health care institutions should be voluntary, educational, and advisory in purpose so as not to interfere with the primary. responsibility and relationship between physicians and their patients.... The recommendations of the ethics committee should be offered precisely as recommendations imposing no obligation for acceptance on the part of the institution, its governing board, medical staff, attending physician, or other persons.

Similarly, the American Hospital Association advises that "[a]n ethics committee should not replace the traditional loci of decision making on these issues." ${ }^{62}$ However, supporting the "hard" model while simultaneously discounting the recommendation seems contradictory; the recommendation is the major difference between the "hard" and "soft" models. In essence, those making such an argument fail to recognize the apparent authority ethics consultants have when issuing

${ }^{58}$ David Thomasma argues that "there is no one set of rules or one method that can ever be articulated adequately." Thomasma, supra note 25 , at 47 . He reasons that ethical consultations are dependent not only on "data about the patient's body and course of disease," but also on "the spirit, the character, the conscience, the value structures of human beings and societies [which] can never be wholly captured in any set of rules and explicit methodology." $I d$.

59 Jonathan D. Moreno, Deciding TOGETHER: Bioethićs AND MORAL CONSENSUS $150-51$ (1995).

${ }^{60} I d$. at 150 .

${ }^{61}$ Fleetwood \& Unger, supra note 15, at 324 (omission in original) (quoting Judicial Council, Am. Med. Ass'n, Guidelines For Ethics Committees in Health Care Institutions, 253 JAMA 2698, 2699 (1985)).

${ }_{62}$ Am. Hosp. Ass'n, Guidelines: Hospital Committees on Biomedical Ethics, in HANDBOOK FOR Hospital ETHICS COMmitreEs 110 (Judith Wilson Ross ed., 1986). 
recommendations, which ultimately negates the classification of the recommendation as "nonbinding."

Advocates for the use of the second model, ${ }^{64}$ which Moreno calls the "soft" model, agree that clinical ethicists should not make the final decisions in the cases for which they are consulted. ${ }^{65}$ They go further, though, arguing that the clinical ethicist should not even issue a recommendation, but rather should have a more impartial role in the consultation process.

In the "soft" model, "the ethics consultant is largely a facilitator, bringing together the relevant parties, helping to sort out the facts, clarifying the problem at hand, raising important moral questions, and noting useful distinctions." ${ }^{66}$ Although other authors do not use Moreno's terms when discussing the issue, there is widespread agreement that the "soft" method of consultation is the more desirable.

Physicians requesting an ethics consultation may want a practical, definitive answer in the form of a recommended course of action, rather than an evenhanded exploration and discussion of the opposing arguments concerning an issue. Such an approach, however,

63 See infra Part IV.B.4 (discussing the apparent authority a clinical ethicist has when issuing a "recommendation").

${ }^{64}$ Other models could theoretically be identified. For example, one model could have the ethics consultant making the final decision in the case. One could also imagine a model in which the clinical ethicist would attempt to convince either the patient or physician that the ethicist's recommended course of action is the only ethically permissible option. Since both of these "models" are really just extensions of the "hard" model, they will not be further elaborated in this Comment. Robert Orr uses the traditional methods of alternative dispute resolution (ADR) as models for discussion of what role clinical ethicists should play in ethics consultation. Orr, supra note 57, at 45-46. Hence, the ADR method of arbitration would advocate the clinical ethicist making a final, binding decision. However, Orr never claims arbitration is the best method of ethics consultation. Id. In his analysis/comparison, Orr also recognizes a fourth potential model of ethics consultation, in which the consultant would "enter[] the conflict at the invitation of one of the parties with the express purpose of advancing that party's cause or position." Id. at 45. Of course, this model is based on the ADR method of negotiation. Again, however, Orr never claims negotiation is the best method of ethics consultation. Id. at 45-46. For a brief discussion of why this model is inappropriate, see Ackerman, supra note 39, at 315-16.

${ }^{65}$ See Ackerman, supra note 16, at 46 ("Since justified moral commitments are socially produced outcomes, the ethicist cannot know what is right independently of the reflective contribution of other members of the moral community."); Ackerman, supra note 39, at 314 ("The specialist in ethics cannot deliver 'right answers' to the moral quandaries faced by health care administrators and clinical care providers."); James F. Drane, Hiring a Hospital Ethicist, in ETHICS CONSUlTATION IN HEALTH CARE, supra note 16 , at 117,127 ("[The ethicist] cannot dictate the right course of action. Mediation is more important than direction.").

MORENO, supra note 59 , at 150 . 
"may infringe on the moral autonomy of those persons they are supposed to serve." According to Sigrid Fry-Revere, the belief that the consultation process should result in a single correct decision is the most serious problem with the current expectations of ethics consultations. ${ }^{68} \quad$ Fry-Revere supports this conclusion by citing that " $[\mathrm{t}] \mathrm{he}$ common law..., the Constitution, and a considerable amount of state statutory law protects an individual's right to make health care decisions based on religious, cultural, and otherwise personal preferences." $^{, 9}$ In fact, without reference to Moreno's classification, FryRevere clearly distinguishes between the "soft" model and the "hard" model:

The role of the bioethics services is not the same as the role of a medical expert. A medical expert helps narrow down the medical options and suggest one best course of action. A bioethics service should work to maximize options and support the legal decisionmaker in whatever ethical perspective he or she chooses. The goal of bioethics consultation is to present as many ethically acceptable options from as many different ethical perspectives as possible. The value of a bioethics consultant is primarily that he or she has studied and/or [has] experience in the types of decisions being made, not that he or she knows what is right. ${ }^{70}$

So, Fry-Revere argues that the clinical ethicist should act as a guide during the consultation, highlighting the important ethical issues that need to be resolved but not offering solutions.

Besides the usurpation of the patient's decision-making authority, other authors argue that "in a secular pluralist society" a final recommendation by the clinical ethicist is inappropriate because "there cannot be a privileged moral position or dominant moral view."71 These authors maintain that the realities of moral and political life demand that the moral claims of the patient be respected even when they differ from those of the clinical ethicist and/or the physician. ${ }^{72}$ In other words, the clinical ethicist must make sure that her role in the ethics consultation is consistent with the fact that health care is as pluralistic as any element of society, especially in an age of increased concern for patient autonomy. The ethics consultation should be "a forum for open discussion ... where those who feel perplexed can

${ }^{67}$ Fletcher \& Hoffmann, supra note 18 , at 336.

${ }^{68}$ Sigrid Fry-Revere, Ethics Consultation: An Update on Accountability Issues, Pediatric Nursing, Jan.-Feb. 1994, at 95, 96.

Id. at 96 .

${ }^{70}$ Id

${ }^{71}$ Casarett et al., supra note 30 , at 7 .

${ }^{72} I d$. 
come and express their doubts, fears, and uncertainties and where others will help them understand .... that there are acceptable options."

It is important to note that although advocates of the "soft" model do not support the clinical ethicist's issuing an ultimate recommendation, many of them do support the reaching of a consensus by the involved parties. For example, George Annas criticized the ethics committee in the Baby $K$ case $^{74}$ because it "'seems to have discussed nothing ethical at all ... it gave advice in medical practice and legal strategy,' whereas it 'should have insisted that discussion with the mother continue until a resolution was reached, and it should have tried to facilitate that communication." "75 David Casarett, Frona Daskal, and John Lantos argue that ethics consultants should only hand down opinions "when the primary issue has been legally resolved or,

${ }^{73}$ Fry-Revere, supra note 68 , at 96 .

${ }^{74}$ In re Baby K; 16 F.3d 590 (4th Cir. 1994). This case concerned a baby who was born with anencephaly, a congenital defect where the brain stem is present but the cerebral cortex is rudimentary or absent. Id. at 592 . Although the physicians recommended only providing the baby with nutrition, hydration, and warmth, the mother insisted that the baby be given mechanical assistance when it developed trouble breathing, and that the baby be resuscitated whenever necessary. Id. at 593. The mother argued that, "as the Baby K's mother and sole guardian, she has the legal and moral right to decide about medical treatment that is in the child's best interest." Sandra Anderson Garcia, Sociocultural and Legal Implications of Creating and Sustaining Life Through Biomedical Technology, 17 J. LEGAL MED. 469, 516 (1996). The hospital sought a declaratory judgment that discontinuation of treatment would not violate any laws. Baby K, 16 F.3d at 592. The court, however, denied the hospital's motion. Id. The Fourth Circuit Court of Appeals upheld the trial court's decision that the hospital could not decline to provide stabilizing treatment to a baby with anencephaly if the mother sought such treatment because such a refusal would violate the Emergency Medical Treatment and Active Labor Act (EMTALA), 42 U.S.C. $\$ 1395$ dd (2000). Baby $K, 16$ F.3d at 598 .

${ }^{75}$ Calvin P. Leeman, John C. Fletcher, Edward M. Spencer \& Sigrid Fry-Revere, Quality Control for Hospitals' Clinical Ethics Services: Proposed Standards, 6 CAMBRIDGE Q. HeALTHCARE ETHICS 257, 258 (1997) (quoting George J. Annas, Asking the Courts to Set. the Standard of Emergency Care-The Case of Baby K, 330 NEW ENG. J. MED. 1542, 1543 (1994)); see also Ackerman, supra note 39, at 313-15 (“[T] he basic function of the specialist in ethics is to facilitate the process by which reflective resolution of moral problems can be achieved."); John La Puma \& David L. Schiedermayer, Ethics Consultation: Skills, Roles, and Training, 114 ANNALS OF INTERNAL MED. 155-60 (1991) ("The consultant [should act] as a rational, clear-headed participant who seeks to help disagreeing parties come to morally permissible conclusions. More often than not, disagreeing parties can agree on a practical solution, although their reasons for agreeing will be different."), reprinted in NANCY S. JECKER, ALBERT R. JONSEN \& ROBERT A. PEARLMAN, Biokthics: An Introduction to the History, Methods, and Practice 283, 287 (1997). 
to put it another way, when a national discourse has produced a consensus that is then imposed by the state."76

Similarly, the Society for Health and Human Values-Society for Bioethics Consultation Task Force on Standards for Bioethics Consultation concludes that the appropriate approach to clinical ethics, which it calls the "ethics facilitation" approach, involves identifying and analyzing the moral issue and facilitating the building of consensus. ${ }^{77}$ More specifically, the clinical ethicist's role should be "to find common ground among conflicting views by posing questions, suggesting strategies, and helping participants to see their own positions relative to those of the other participants." ${ }^{, 78}$ The ethicist may suggest a compromise between the parties, but she must be sure that the arguments in favor of such a conclusion are convincing and ultimately acceptable to all involved parties. ${ }^{79}$ Only if a consensus is reached can the clinical ethicist be assured that the resolution of the disagreement has moral validity. ${ }^{80}$

\section{WHY IS THE LEGAL LIABILITY OF CLINICAL ETHICISTS EVEN AN ISSUE?}

According to Annas, "Good ethics committees begin where the law ends." If that is the case, though, then why do clinical ethicists need to be concerned about potential legal liability?' Since "[b]oth law and ethics are ... normative and so aim to distinguish between acceptable and unacceptable behaviour by reflecting public opinion and current mores, ${ }^{, 82}$ it would appear that if the clinical ethicist offered an ethically permissible recommendation or facilitated an ethically permissible consensus, then her recommendation or facilitating action would also be legal. It is clear, however, that "legal" and "ethical" are not always synonymous. For example, "ethical actions may be legal or illegal"; ${ }^{83}$ although third trimester abortions (also called "partial-birth"

${ }^{76}$ Casarett et al., supra note 30 , at 7.

77 See Aulisio et al., supra note 10, at 61 (describing the "ethics facilitation" approach and explaining that the Task Force favored the that approach over both the "authoritarian" and the "pure facilitation" approaches).

${ }^{78}$ Casarett et al., supra note 30 , at 9 .

${ }^{79}$ Id. at 8.

${ }^{80}$ See id. (arguing that for a standard to be valid, it must be approved by all those affected).

${ }^{81}$ Annas, supra note 14, at 20-21.

${ }^{82}$ Hendrick, supra note 21 , at i50.

${ }^{83}$ Susan M. Bauman, Clinical Ethics: What's Law Got to Do with It? 8 ARCHIVES FAM. MED. 345, 346 (1999). 
abortions) have been banned in approximately thirty states in this country $^{84}$ and are restricted in many other states, ${ }^{8.5}$ even some who would otherwise take a right-to-life stance might argue that abortion is an ethical option when a fetus is discovered to have Down syndrome. ${ }^{86}$ Similarly, "laws may be ethical or unethical," the success of the civil rights movement of the 1960s in abolishing unethical segregation laws. ${ }^{88}$ These dichotomies are often attributed to the fact that "law is a product of political haggling and compromise."

It is important to recognize, however, that lawmakers" "may be seen as articulating the collective wisdom of our society (or at least, its majority view).", Hence, the fact that liability is an issue for clinical ethicists tells us something about what at least a majority of society thinks about making ethical decisions in medicine. As Paul Wolpe explains, "Pursuit of autonomy has become dominant in the American model of medical decision making." As concern over patient autonomy has increased, "the acceptance of paternalism as appropriate in medicine" has necessarily decreased." This lack of respect for author-

${ }^{84}$ Sunny Kaplan, States Grapple with Late-Term Abortion Bans, Stateline (Nov. 12, 1999), at http://www.stateline.org/story.do? storyld=51486.

${ }^{85}$ For a summary of various types of abortion laws throughout the country, see Abortion Law Homepage, State Abortion Lavus: A Survey, at http://members.aol.com/ abtrbng/stablw.htm (last visited Nov. 18, 2002).

${ }^{86}$ See, e.g., Noreen M. Glover \& Samuel J. Glover, Ethical and Legal Issues Regarding Selective Abortion of Fetuses with Down Syndrome, 34 MENTAL RETARDATION 207, 208 (1996) (citing Laura Hershey, Choosing Disability, Ms., July-Aug. 1994, at 26, for the proposition that "persons who otherwise describe themselves as pro-life advocates may ... . make exceptions based upon the health ("normality') of the fetus").

${ }^{87}$ Bauman, supra note 83 , at 346 . The University of Pennsylvania would probably disagree, though, as its motto, "leges sine moribus vanae," means "laws without morals are worthless." Univ. of Pa., Office of Univ. Communications, Penn News: Frequently Asked Questions, at http://www.upenn.edu/pennnews/faqs.html\#nine (last visited Dec. $3,2002)$.

S8 See AHronheim, Moreno \& ZUCKERMAN, supra note 31, at 10 ("[O]ften the law is itself immoral. The civil rights movement of the 1960 s rested on this premise ....").

89. $I$.

90 The term "lawmakers" here refers not only to the politicians who literally write laws, but also to judges who; through their actions interpreting the black-letter law, create the common law.

"1) Bauman, supra note 83, at 345 .

${ }^{92}$ Paul Root Wolpe, The Triumph of Autonomy in American Bioethics: A Sociological Viez, in BIOETHICS AND SOCIETY: CONSTRUCTING THE ETHICAL ENTERPRISE 38, 46 (Raymond DeVries \& Janardan Subedi eds., 1998).

${ }^{99}$ Donnie J. Self \& Joy D. Skeel, Legal Liability and Clinical Ethics Consultations: Practical and Philosophical Considerations, in MEDICAL. ETHICS: A GUIDE FOR HEALTH Professionals 408, 414 (John F. Monagle \& David C. Thomasma eds., 1988). 
ity has been cited as a cause of the increasingly.litigious nature of society. ${ }^{94}$

Leaders of the community (i.e., those with higher education in general, but especially those in positions of authority, like doctors, lawyers, teachers, and clergy) used to be respected and trusted, such that only gross violations of professionalism would incite a lawsuit. ${ }^{95}$ Now, however, "when anything is not completely satisfactory, the response that comes to mind first (rather than last) is 'Sue for whatever you can get." ${ }^{, 96}$ Since patients no longer trust that their personal physicians will always do what is in their best interests, they certainly do not trust that a clinical ethicist, whom they usually have not met or even heard mention of before the consultation, will necessarily act in their best interests.

Some argue that this change is due to the growing acceptance of the idea that values are subjective, rather than objective. ${ }^{97}$ That is, they are relative to the person making the moral judgment, as opposed to relative to the circumstances. ${ }^{98}$ Donnie Self and Joy Skeel at- tribute this change, in part, to the rise in popularity of existentialism because " $[\mathrm{t}]$ he subjectivism of existentialism maintains that moral judgments are merely expressions of emotions, preferences, or decisions and do not make truth claims-and so cannot be true or false."99 They explain existentialism in the following manner:

Existentialism explicates right and good in terms of freedom. It holds that with respect to basic life-constituting decisions, one is completely free to choose whatever lifestyle one pleases. No reason can be given for the choice; and the choice cannot be wrong, for choice at this level defines what is right. ${ }^{100}$

Therefore, according to Self and Skeel, though a stranger to our modern American society, Albert Camus could be responsible for the

${ }^{94}$ As stated by Self and Skeel, "Currently anyone can get sued for anything by anybody." Id. at 410 .

Id.

Id.

${ }^{97}$ Id. at 412-14. But see Wolpe, supra note 92, at 43-46 (arguing that "[t]here is no inherent reason that autonomy must become the primary ethical principle in a medical tradition," and concluding that the reason why pursuit of autonomy has become dominant is "because its application is comparatively [to other popular principles] straightforward and uncontroversial").

${ }^{8}$ Self \& Skeel, supra note 93 , at 413.

9 Id. at 414.

${ }^{100} \mathrm{Jd}$. 
plague of patient autonomy that is affecting the health care system today. ${ }^{101}$

Paternalism in medicine has also been affected by recent changes that are wholly unrelated to patient autonomy. First, advances in medical technologies have occurred at such a rapid pace that consensus about what ethical canons should dictate their usage has never really been formed. ${ }^{102}$ Therefore, discussion of ethical concerns is warranted, in fact desired, to ensure that the proper result is reached in each particular instance. Second, "[p] ublic investment in the financing of health care, in both governmental and non-governmental arrangements, has generated a more sharply defined public interest in the disposition of these [public] funds." ${ }^{103}$ In other words, people want to be sure that their financial contributions to the health care of other people are being utilized in a fashion consistent with their conceptions of what is ethically appropriate. ${ }^{104}$ For example, if the government extended Medicare coverage to include physician-assisted suicide, there would be great public outcry because everybody's tax dollars contribute to the Medicare fund and not everyone considers physician-assisted suicide to be ethically permissible.

Another reason, more particular to ethics consultation, for clinical ethicists to be concerned about potential liability is well articulated by William dePender and Wanda Ikeda-Chandler. They write:

Conflict and litigation are often a by-product of suspicion. Suspicion grows when important concerns are ignored. Suspicion breeds fear. Fear increases the possibility of misunderstanding. And the cycle con-

\footnotetext{
101 Albert Camus was, beside Jean-Paul Sartre, the premier existentialist author.

102 See Ahronheim, Moreno \& ZUCKERMAN, supra note 31, at 12 ("In recent years, ... modern medicine technologies have created familiar uncertainties about the application of traditional ethical canons.").

${ }_{103}^{103}$ Id.

104 One illustration of this increased concern for the ethical validity of ventures undertaken with public funds is the debate surrounding President Bush's statements on August 9, 2001 regarding public funding for stem cell research. For various arguments in the debate on public funding for stem cell research, see Susan Baer, SenatorPhysician Backs Stem Cell Study; Frist Favors Funding Research on Embryos, BALT. Sun, July 19, 2001, at 1A; Editorial, Ethics at Life's Threshold, OREGoNiAN, July 13, 2001, at D10; Editorial, Federal Funds Should Be Used for Stem Cell Experimentation, PANTAGRAPH (Bloomington, Ill.), July 22, 2001, at C2; Tim Friend, What Is at Stake?, CHI. Sun-TimES, Aug. 10, 2001, at 8; Helen Kennedy, Researchers Wary of Bush Stem Cell Ruling, DAILY News (N.Y.), Aug. 11, 2001, at 8; Editorial, No Funds for Stem Cell Research, WASH. TIMES, July 11, 2001, at A16; Jaime Talan, Scientists Cautious on Limits to Work, NEWSDAY (N.Y.), Aug. 11, 2001, at A6. Government money funds a multitude of medical research ventures, but no other debate about the ethical permissibility of the research has occurred in such a highly publicized form in the recent past.
} 
tinues. This cycle breaks out into public view when legal action is taken, but the cycle itself isn't broken.

If a clinical ethicist fails to communicate effectively with the participants in the consultation, ${ }^{106}$ those participants are more likely to be suspicious of the entire process, and therefore of the consultant herself. This becomes more true as the role of the patient and/or physician in the consultation is increasingly minimized or marginalized.

As Candace Evans Blades and Michael Paul Curreri explain, "Someone who feels as though they have had some control over the decision-making process is more likely to be satisfied with a [clinical ethicist] than someone who feels that he or she was somehow "coerced' by a [clinical ethicist] into agreeing with a particular decision." 107 This leads to the hypothesis that if a clinical ethicist wants to decrease her exposure to potential liability, she should adhere to the "soft" model of consultation and avoid making recommendations; if patient and physician alike are satisfied with the process and outcome of the consultation, they are not very likely to sue. This hypothesis will be tested in the next Part where the potential liability is analyzed in detail, and the "hard" and "soft" models are compared in this light.

\section{WHAT IS THE Potential (ThEORETICAL) LEGAL Liability OF A CLINICAL ETHICIST?}

As discussed above, patients are likely to sue when they are harmed by a decision they feel was imposed upon them. ${ }^{108}$ Therefore,

105

William DEPENDER \& WANDA IKeda-Chandler, Clinicil ETHICS: AN INVITATION TO HEALING Professionals 9 (1990).

${ }^{106}$ For example, ineffective communication by the ethicist could lead to the patient and/or physician not understanding the other's views, or the patient and/or physician not understanding why the ethicist believes what she believes.

${ }^{107}$ Candace Evans Blades \& Michael Paul Curreri, Law, Ethics, and Health Care: An Analysis of the Potential Legal Liability of Institutional Ethics Committees, [1989 Ed., Vol. 2, Updates and Special Sections] BioLaw (Univ. Pub. Am.) S:317, S:319 (Dec. 1989); see also Edmund G. Howe, When Physicians Impose Values on Patients: An Ethics Consultant's Responsibilities, in ETHICS CONSULTATION IN HEALTH CARE, supra note 16, at 137, 143-47 (arguing that an ethics consultant "should stress the existence and rationale of the ethical consensus rather than his or her personal view" because physicians and patients "will be less likely to perceive the consultant as attempting to impose his or her idiosyncratic bias and more likely to focus on the reasoning behind that position," and concluding that "the most effective ethics consultant will be the one who provides illumination rather than persuasion").

${ }^{108}$ If a physician is sued by a patient, the physician may turn and sue the clinical ethicist in order to shift some or all of the blame. The doctor could argue that the ethicist was negligent in her consultation, and that the physician's decision was influ- 
lawsuits are most likely to occur' in cases where clinical ethicists are authorized to make binding decisions. Lawsuits are also a potential reality for ethics consultants who make "nonbinding" recommendations because although the recommendations are not explicitly imposed, they may be implicitly enforced because of the ethicists' apparent moral authority. ${ }^{109}$ This risk increases if the ethicist, though offering a nonbinding recommendation, attempts to, and in fact does, convince one of the two parties to acquiesce. In contrast, ethics consultants who follow the "soft" model of consultation are much less likely to have a lawsuit filed against them because both the patient and the physician will have participated fully in the decision-making process.

However likely or unlikely a lawsuit may be, nothing can really stop an unhappy patient from filing suit against a clinical ethicist who consulted the patient and her physician about a medical decision. As I will show, the likelihood of actually being found liable for one's part in an ethics consultation depends on the role played by the clinical ethicist: the ethicist who issues a binding decision is most likely; she who issues a nonbinding recommendation, but convinces the parties to choose one option over another is somewhat likely; the ethicist who simply issues a nonbinding recommendation is less likely; and finally, the consultant who strictly adheres to the "soft" model of ethics consultation is unlikely to be found liable for any intentional torts or negligent behavior. ${ }^{110}$

\section{A. Intentional Torts}

Theoretically, a clinical ethicist could be held civilly liable for a number of intentional torts. At first glance, it would appear that since clinical ethicists do not actually perform procedures on patients, a theory of vicarious liability would be the only means of holding a clinical ethicist liable for an intentional tort such as assault, battery, or false imprisonment. However, the actions of a clinical ethicist in-

enced by the ethicist's erroneous guidance. The physician would also have to argue that the clinical ethicist owed a particular duty to him. See infra Part IV.B (detailing the legal elements of negligence).

${ }^{109}$ See infra Part IV.B.4 (discussing the possibility and policy reasons for considering a nonbinding recommendation as sufficient proximate causation in a prima facie case of negligence).

${ }^{110}$ To be thorough, I did evaluate the potential for a clinical ethicist to be held criminally liable for her role in an ethics consultation. However, since I found criminal liability to be extremely unlikely, I did not include the discussion in this Comment. 
volved in a case consultation could themselves be considered tortious, such that she could be held directly liable for an intentional tort.

\section{Vicarious Liability}

"Vicarious liability" is defined as "[1]iability that a supervisory party ... bears for the actionable conduct of a subordinate or associate ... because of the relationship between the two."111 The most common, ${ }^{112}$ and only potentially applicable, form of vicarious liability is the master-servant rule (respondeat superior). ${ }^{113}$

The main requirement of the master-servant relationship is that the master controls or has the right to control the conduct of the servant. $^{114}$ In order for liability to extend to the clinical ethicist, therefore, she would have to be able to control the conduct of the physician. ${ }^{115}$ An ethicist who issues a binding decision clearly controls the conduct of the physician, and hence, would be found vicariously liable for the physician's tortious conduct under the master-servant rule. An ethics consultant who merely convinces the parties to act in a certain manner could also be found vicariously liable for the physician's tortious act. A plaintiff's main obstacle in such a situation would be actually proving that the physician was, in fact, convinced and hence controlled by the ethics consultant. However, an ethicist who issues a

111 BLACK'S LAW DICTIONARY 377 (pocket ed. 1996).

112 See JAMES A. Henderson, JR. ET AL., THE TORTS Process 165 (4th ed. 1994) ("The central principle establishing vicarious liability for the tortious conduct of another is [respondeat superior].”).

${ }^{113}$ For an excellent discussion of the legal doctrines courts have used to find vicarious liability in the health care context, see Sword v. NKC Hosps., Inc., 714 N.E.2d $142,147-49$ (Ind. 1999).

114 See Restatement (SECOND) OF AGENCY $\$ 220$ (1958) (defining "servant"). The other requirement is that the servant was acting in the scope of her employment, or, if the servant was not acting within the scope of her employment:

(a) the master intended the conduct or the consequences, or (b) the master was negligent or reckless, or (c) the conduct violated a non-delegable duty of the master, or (d) the servant purported to act or to speak on behalf of the principal and there was reliance upon apparent authority, or he was aided in accomplishing the tort by the existence of the agency relation.

Id. $\$ 219$. This requirement would be easy to meet because the physician's (i.e., servant's) actions in relation to the patient would clearly be within the scope of her employment.

${ }^{115}$ The comment on subsection 1 of the Restatement section 220 specifically distinguishes between a servant, for whose conduct the master could be liable, and an independent contractor, for whose actions the master could not be liable. It states, "Those rendering service but retaining control over the manner of doing it are not servants." $I d . \$ 220 \mathrm{cmt}$. e. 
nonbinding recommendation, or no recommendation at all, does not exercise control over the physician in charge of the patient's care. ${ }^{116}$ Therefore, the ethicist could not be considered the physician's master, and could not be held liable under the master-servant rule for the physician's tortious conduct.

Since no form of vicarious liability is applicable to the clinical ethicist when issuing a nonbinding recommendation, some action of the ethicist would have to be tortious in and of itself in order for her to be found liable for an intentional tort. ${ }^{117}$ This is in contradistinction to the master-servant rule, under which the master is not liable for any wrongful action of her own, but rather for the tortious acts of someone acting on her behalf, someone over whom she exercises control. According to basic rules of tort law, one could be subject to liability for an injury to another if her conduct that caused the harm "is generally culpable and not justifiable under the circumstances. . . a although the actor's conduct does not come within a traditional category of tort liability."118 This general rule is applied in a variety of ways. For instance, one could be liable for the tortious conduct of another if the two were acting in concert ${ }^{119}$ or if one directed or permitted the other to act in a tortious manner. ${ }^{120}$

\section{Acting in Concert}

As delineated by the Restatement (Second) of Torts, one could be liable under the "acting in concert" rubric for the harm actually caused by the tortious conduct of another in three circumstances. ${ }^{121}$

${ }^{116}$ But see infra Part IV.B.4 (arguing that the ethicist may speak with such compelling authority that the physician and/or patient are effectively left with no choice at all). That line of reasoning, however, would lend support to the arguments offered below that the clinical ethicist's acts of encouragement or advisement are themselves tortious.

${ }^{117}$ See Rowe v. Lewis, 632 F. Supp. 1397, 1402 (D. Mont. 1986) ("In the absence of vicarious liability, plaintiff must allege some actions [of the defendants] to support a claim against them.").

118 RESTATEMENT (SECOND) OF TORTS $\$ 870$ (1979).

${ }^{119}$ See id. $\$ 876$ (defining the liability for persons acting in concert).

${ }^{120}$ See id. $\$ 877$ (defining the liability for a person directing or permitting the tortious conduct of another).

${ }^{121} I d$. $\$ 876$. This theory of civil liability through "acting in concert" is similar to "accomplice liability" in criminal law. Under the accomplice liability theory, the accomplice is guilty of the same substantive crime that she helped the principal perpetrator to commit, even if she is not a "but for" cause of the event (she could simply encourage the commission of the crime). See Model Penal Code $\$ 2.06$ (1962) (defining situations where a person is criminally liable for the conduct of another). 
The first situation is if one "does a tortious act in concert with the [tortfeasor who actually caused the harm] or pursuant to a common design with [that tortfeasor]." ${ }^{22}$ This would not be applicable to the clinical ethicist's situation because she would not have committed a tortious act against the patient herself. The second situation is if one "knows that the [harming tortfeasor's] conduct constitutes a breach of duty and gives substantial assistance or encouragement to the other so to conduct himself." Presumably, a clinical ethicist would not direct, advise, or encourage a physician to commit an act that she knows is tortious. In the unlikely instance that she did so, though, she could be held liable for the resulting harm to the patient.

The last situation requires that the actor's "own conduct, separately considered [from the conduct of the harming tortfeasor], constitutes a breach of duty to the third person." ${ }^{24}$ In other words, in order for a clinical ethicist to be held liable for an intentional tort committed by a physician under this theory of liability (1) she must have had a duty to the patient, (2) she must have breached that duty, and (3) her actions must have been "a substantial factor in causing the [resultant harm]."125 This is the standard for negligence. ${ }^{126}$ Therefore, if a clinical ethicist were found negligent, ${ }^{127}$ she could also be held liable for any foreseeable ${ }^{128}$ intentional tort committed by the physician. Presumably, a clinical ethicist would make clear to a physician that the physician should not commit a foreseeable tortious act. However, in the unlikely instance that the ethics consultant did not do so, she could be held liable for the resulting harm to the patient.

\section{Directing or Permitting Conduct}

As section 877 of the Restatement (Second) of Torts explains, one may be held liable for the tortious conduct of another if he "orders or induces the conduct, [or] if he knows or should know of circum-

122 RESTATEMENT (SECOND) OF TOR'S $\$ 876$ (a) (1979).

${ }^{123}$ Id. $\$ 876(\mathrm{~b})$.

${ }^{124}$ Id. $\$ 876(\mathrm{c})$.

${ }^{125}$ Id. $\$ 876 \mathrm{cmt}$. e.

${ }^{126}$ See infra Part IV.B (stating the required elements of negligence).

${ }^{127}$ For an analysis of the clinical ethicist's potential liability under a theory of negligence, see infra Part IV.B.

${ }^{128}$ The actor must have had "reason to know" that the harmer would act in such a tortious manner. See Restatement (SECOND) OF TORTS $\$ 876 \mathrm{cmt}$. e, illus. 12-14 (1979) (presenting situations where a reasonable belief that an act was not tortious negates liability). 
stances that would make the conduct tortious if it were his own." ${ }^{129} \mathrm{Al}-$ though this sounds like a theory of vicarious liability, in fact the act of ordering or inducing the conduct is itself what is considered tortious. $^{190}$ Even though the ethicist did not personally touch the patient, it would be sufficient for a finding of liability that the ethicist intended the conduct or its consequences, and persuaded another to engage in such conduct. ${ }^{131}$ For example, if $A$ intends to touch $B$ without $B$ 's permission but does not intend to harm $B$, the fact that $A$ intends to touch $B$ without her permission and that $B$ is harmed is sufficient to make $A$ liable to $B$ for battery. ${ }^{132}$ Even if no physical harm to $B$ occurs, $A$ is liable to $B$ for battery if the contact is "offensive." ${ }^{\text {"133 }}$ This theory of liability could be applicable to three of the four possible consultation formats discussed in Part II.B.

\section{a. Ethicist issuing a binding decision}

Most clearly, if a clinical ethicist issues a binding decision, she will be found liable for an intentional tort committed by the physician because the ethicist will have "ordered" the tortious conduct. For example, if a clinical ethicist involved in the example provided in Part I.B ordered the physician to ignore the patient's objections, restrain her, and perform the hysterectomy, the ethicist would clearly be liable for the resulting intentional torts (assault, battery, and false imprisonment).

\section{b. Ethicist issuing a nonbinding recommendation, but convincing the parties to accept her proposal}

If a clinical ethicist issues a nonbinding recommendation, but then also attempts to persuade either the physician or patient to accept her proposal, she could be found liable for an intentional tort committed by the physician. In a suit arising from this situation, the plaintiff (either patient or physician) would have to prove that the

120) $l d . \S 877$ (a).

${ }^{130}$ In the comment on this clause, the Restatement reads, "In many of the situations that would come within the rule stated in this Clause, the person giving the order or inducement would be liable on the ground that he was principal or master; the rule, however, is independent of the existence of liability on this ground." $I d . \$ 877 \mathrm{cmt}$. a.

${ }^{131}$ See id. $\$ 870 \mathrm{cmt}$. b ("For certain early developing torts, such as assault, battery and false imprisonment, it is held not to be necessary to intend to harm the plaintiff, but intent to commit the tort (or a similar one) on a third person is sufficient.").

${ }_{132}^{132}$ See id. $\$ 13$ (defining battery for harmful contact).

138 See id. $\$ 18$ (defining battery for offensive contact). 
physician would have acted differently if the ethicist had not made the particular recommendation. ${ }^{134}$ This would satisfy the "inducement" requirement. In a situation where the ethicist convinced the patient to "consent" to the procedure, the ethicist could argue that the patient's "consent" made the act privileged, thereby barring the patient's recovery. ${ }^{135}$ In order to defeat this defense, the plaintiff would have to prove that the patient's acquiescence was not true consent (i.e., it was coerced or it was not fully informed), and therefore did not confer a privilege to the contact.

So, for example, if a clinical ethicist involved in the example provided in Part I.B issued a nonbinding recommendation, but then convinced the patient to undergo the surgery, the ethicist could be liable for the resulting intentional torts (assault, battery, and false imprisonment) if the plaintiff could prove that (1) the physician would not have performed the hysterectomy if the ethicist had not tried to persuade her, and (2) the patient only "consented" because she was coerced.

\section{c. Ethicist issuing nonbinding recommendation}

If a clinical ethicist issues a nonbinding recommendation, it is unlikely that she will be found liable for an intentional tort committed by a physician, but it is possible. The requirements for holding an ethicist liable in such a situation are the same as those required when the ethicist attempts to convince the parties to pursue one option over another. ${ }^{136}$ In this situation, however, the plaintiff would have a much more difficult time proving both "inducement" and "coercion" because the ethicist made no active attempts to persuade either the patient or physician.

\section{d. Ethicist facilitating consensus, with no recommendation}

If a clinical ethicist simply facilitated true consensus between the patient and physician, the ethicist could not be found liable for the tortious acts of the physician. First, as mentioned previously, if both the patient and physician are satisfied with the process and outcome

\footnotetext{
${ }^{134}$ For a discussion of causation, which relates to the argument by a physician or patient that the ethicist's recommendation persuaded the physician's conduct, see infra Part IV.B.4.

${ }^{135}$ See HENDERSON ET AL., supra note 112, at 34-59 (explaining how consent produces a privilege to inflict contact, which defeats a plaintiff's prima facie case).

${ }^{136}$ Supra Part IV.A.3.b.
} 
of the consultation, they are not very likely to sue. ${ }^{137}$ However, if a true consensus supported the committing of a tortious act, and one of the parties sued, the clinical ethicist would be able to successfully defend the suit by arguing that the patient's consent made the act privileged. The plaintiff would be unable to prove that the patient was coerced into "consent" by the ethicist because the ethicist would not have expressed an opinion of her own.

\section{B. Negligence}

If legal action were ever brought against a clinical ethicist, it would most likely be in the form of a civil suit for negligence. Negligence is defined as " $[\mathrm{t}]$ he failure to exercise the standard of care that a reasonably prudent person would have exercised in the same situation." 198 Therefore, in order to be found negligent, four essential elements must exist: duty, breach of duty, causation, and harm (or damages). ${ }^{139}$ In nonlegal terms, this means that for someone to be found negligent and therefore liable for damages to another person, the following conditions must exist: (1) the person who caused the harm must have had a duty to act in a reasonable manner (i.e., according to a specific standard of care) toward the harmed; (2) the person who caused the harm must have breached that duty (i.e., the person who caused the harm did not act according to that standard of care); (3) the harmed must have, in fact, been harmed; and (4) the actions of the person who caused the harm (or lack of action by that person) must have been the actual and proximate cause of the harm to the harmed.

\section{Duty}

It is not absolutely clear that the first element of negligence, the existence of a duty to the patient, would be present in the case of a clinical ethicist case consultation. It is often debated whether the duty of the ethicist is to the patient or to the physician. Some authors argue that since the physician is usually the one who calls for the ethics consultation, the physician is the client of the clinical ethicist, and therefore, the ethicist's duty is to the physician. Self and Skeel make such an argument, maintaining that "if traditional understanding of

\footnotetext{
${ }^{137}$ Supra Part III.

${ }^{138}$ BLACK'S LAW DICIIONARY 434 (pocket ed. 1996).

${ }^{139}$ Id.
} 
consultations in the medical setting is applied to ethics consultations, then clearly the client or recipient of the efforts of a clinical ethicist is the physician." 140

Andrew Merritt disagrees. He states, "Just as a consulting physician owes a duty of care to the patient even if he or she does not meet directly with the patient, [clinical ethicists] should owe a duty of care to patients whenever they are consulted to further the interests of those patients." ${ }^{141}$ In fact, Merritt argues that some consider the clinical ethics consultant to be a "champion of the patient's interests, safeguarding the patient from the competing interests of the hospital or the medical staff." ${ }^{142}$ Gordon Duval does not go that far, but argues that it is conceivable that a court would find the clinical ethicist to be in a "fiduciary relationship to the patient who is the subject of his advice." Duval defines a fiduciary relationship as "one of trust and dependence that in the medical context imposes upon the medical practitioner a family of particular obligations to patients, including those of utmost good faith and loyalty, honesty, respect for confidential information, and an obligation to act in the patient's best interests."144 Yet, others simply argue that if the clinical ethicist owes no conflicting duty to others, her obligation may be found to run to the patient. ${ }^{145}$

There are critics, however, who believe that "the consultant works for both the physician and the patient." 146 This concept opens the door for double liability-first to the patient and then to the doctor on behalf of the patient. It seems likely that a court would find that an ethics consultant owes a duty to the patient to act in a reasonable fashion because the potential harm to the patient is clearly foreseeable. Similarly, a court would probably find that a clinical ethicist also owes a duty to the physician to perform a consultation in a nonnegligent manner.

${ }^{140}$ Self \& Skeel, supra note 93 , at 409.

141 Merritt, supra note 3, at 1283.

${ }^{142}$ Id. But see Ackerman, supra note 39, at 315 (arguing that "ascribing a 'patient advocate' role to the consulting ethicist" is inappropriate).

${ }^{14.3}$ Gordon Duval, Liability of Ethics Consultants: A Case Analysis, 6 CAMBridGE Q. HEALTHCARE ETHICS 269, 272 (1997); see also Laurence B. McCullough, The History of Medical Ethics Is Crucial for a Critical Perspective in the Continuing Development of Ethics Consultation, AM. J. BIOETHICS, Fall 2001, at 55, 56 (reasoning that the history of medical ethics supports the ethics consultant being a fiduciary of the patient).

144 Duval, supra note 143, at 272.

145 Blades \& Curreri, supra note 107, at 320.

${ }^{146}$ La Puma \& Schiedermayer, supra note 75, at 288. 
But does a clinical ethicist who was involved in a case consultation have a duty to protect the patient when the doctor chooses a course of action which is contrary to the ethicist's recommendations and which the ethicist believes will harm the patient? John Robertson argues that

courts would probably find that if [a medical] consultant was clearly aware of improper management that would harm the patient, it would be his or her duty to protect the patient [because by] agreeing to advise the physician about this case, he or she takes on a duty to act for the patient's best interests. $^{147}$

Since a medical consultant has such a duty, there is no good reason why the clinical ethicist should be treated differently. ${ }^{148}$ It should be made clear, however, that the evidence of harm and the need for intervention would have to be clear and strong for the courts to recognize and impose this additional duty. ${ }^{149}$

\section{Breach of Duty}

The second element of negligence, that the clinical ethicist breached her duty to the patient, is also problematic in the case of a clinical ethicist involved in case consultation. The reason for this difficulty is that there is no universally agreed-upon standard for what skills one needs to possess in order to be qualified to act as a clinical ethicist. $^{150}$ In fact, it is one of the most debated issues concerning clinical ethics-everyone seems to have an opinion about what that standard should be. ${ }^{151}$ The most comprehensive articulation of the core competencies clinical ethics consultants should possess comes from a task force formed by the Society for Health and Human Values and the Society for Bioethics Consultation. ${ }^{152}$ The Task Force Report

${ }^{147}$ John A. Robertson, Clinical Medical Ethics and the Law: The Rights and Duties of Ethics Consultants, in ETHICS CONSUltation IN HEALTH CARE, supra note 16, at 157, 169.

148 Id. at 169 .

$149 \mathrm{ld}$.

150 For discussions of what skills a clinical ethics consultant should possess, see MORENO, supra note 59, at 152; Aulisio et al., supra note 10, at 61-64; Duval, supra note 143, at 272-75; Fry-Revere, supra note 68, at 96; La Puma \& Schiedermayer, supra note 75 , at 289 .

${ }^{151}$ See sources cited supra note 150 (presenting differing opinions concerning the capabilities necessary to be a clinical ethics consultant).

${ }^{152}$ TASK FORCE REPORT, supra note 51, at 11-21; see also Aulisio et al., supra note 10 , at 61 (writing a position paper for the Task Force, summarizing and discussing these core competencies). The American Society for Bioethics and Humanities (ASBH) 
lists skills in assessment, ${ }^{158}$ process, ${ }^{154}$ and interpersonal relations; ${ }^{155}$ knowledge in nine specific areas; ${ }^{156}$ and eight character traits ${ }^{157}$ as essential for a clinical ethicist. Skills, areas of knowledge, and character traits listed by other authors, though worded differently, generally fit into the categories delineated by the Task Force.

The breach of duty requirement is also difficult to interpret in the case of a clinical ethicist because "the effective practice of ethics consultation might depend as much or more on the institutional or social circumstances of the consultation," than on the "qualifications of the ethics consultant." ${ }^{158}$ Evaluation of these social or institutional circumstances is not only more difficult, but it would also shift the focus from the individual ethicist and her actions to forces outside her control (e.g., the participants' expectations of the consultant, or the institution's perception and treatment of ethics consultations generally). This would also effectively shift the blame from the individual ethicist, whom the court could hold responsible for the outcome, to indeterminate systematic and structural processes, which would leave the plaintiff without effective recourse. However, in faimess to the clinical ethicist, a court would probably have to consider these factors

later adopted the Task Force Report. Id. at 59.

${ }^{153}$ Some examples of ethical assessment skills, as provided by Aulisio et al., are "the ability to distinguish the ethical dimensions of the case from other, often overlapping dimensions (such as legal, medical, and psychiatric aspects), and the ability to identify and justify a range of morally acceptable options and their consequences." Aulisio et al., supra note 10 , at 61 .

${ }^{154}$ Facilitation is one example of a process skill. $I d$.

155 Since "ethics consultations often revolve around communication occlusions of various sorts," George J. Agich, The Question of Method in Ethics Consultation, AM. J. BIOETHICS, Fall 2001, at 31, 35, interpersonal skills are probably the most crucial com. petencies for a clinical ethicist to possess. Two obvious, but important, illustrations of these skills are "the ability to listen well and communicate interest, respect, support, and empathy to involved parties and the ability to represent the views of involved parties to others." Aulisio et al., supra note 10, at 61 .

${ }^{156}$ Specifically, these nine areas are

moral reasoning and ethical theory, bioethical issues and concepts, health care systems, clinical context, knowledge of the local health care institution in which consultation is done, the local health care institution's relevant policies, beliefs and perspectives of patient and staff population, relevant codes of ethics and professional conduct and guidelines of accrediting organizations, and relevant health law.

Aulisio et al., supra note 10, at 61-62.

${ }^{157}$ The eight character traits specifically mentioned by the Task Force are "tolerance, patience, compassion, honesty, courage, prudence, humility, and integrity." Id. at 64.

${ }^{158}$ Agich, supra note 155 , at 36. 
when determining whether or not the ethicist breached her duty to the patient.

Duval provides another slightly problematic view of what would entail a breach of duty. He explains that "[c]ourts tend to accept as nonnegligent and therefore not giving rise to liability professional practices that are accepted by at least a reasonably substantial and authoritative segment of the profession." ${ }^{159}$ However, it is unclear whether or not clinical ethics consultation should be considered a "profession." Additionally, even if clinical ethics consultation is considered a profession, it is not clear exactly who is a member of this "profession." Therefore, it is not clear whom would be called before a court to testify as to the appropriate standard of care of the clinical ethicist. In fact, many courts have been reluctant to recognize clinical ethicists (or bioethicists, in general) as experts. ${ }^{162}$

There does appear to be a resolution to this problem, though. It has been argued that

[s]ince there is not an obviously right or wrong answer in many ethical problems, the defense of error of judgment may be invoked. What is involved is not a lack of skill so much as an exercise of the health care ethicist's judgment at the relevant time, and the court may be reluctant to say that choosing a certain ethical option was negligent. ${ }^{1 .}$

Therefore, even without a clearly established standard of care for the clinical ethicist in a case consultation, if the clinical ethicist "acted in good faith, with due care, without malice, and in conformity with thoughtful procedures and thorough investigation of facts, and [her]

${ }^{159}$ Duval, supra note 143, at 275.

${ }^{160}$ See Wesley J. Smith, The Question of Method in Ethics Consultation: Transforming a Career into a Profession?, AM. J. BIOETHICS, Fall 2001, at 42, 42-43 ("[Ethics consultants] cannot be transformed into medical professionals by promulgating rules and methods to direct their activities.... [I]n the end the future of ethics consultation is selflimiting.").

${ }^{161}$ See supra notes $150-51$ and accompanying text (explaining that there is no agreed-upon standard for who is qualified to act as a clinical ethicist).

${ }^{162}$ This is a widely debated issue, to which I cannot do justice in this Comment of limited focus. For discussions of this issue, see Alexander Morgan Capron, Facts, Values, and Expert Testimony, Hastings Center ReP., Sept.-Oct. 1993, at 26; John C. Fletcher, Bioethics in a Legal Forum: Confessions of an "Expert" Witness, 22 J. MED. \& PHIL. 297 (1997); Virginia A. Sharpe \& Edmund Pellegrino, Medical Ethics in the Courtroom: A Reappraisal, 22 J. MED. \& PHIL. 373 (1997); Bethany Spielman \& George Agich, The Future of Bioethics Testimony: Guidelines for Determining Qualifications, Reliability and Helpfulness, 36 SAN DIEGo L. REv. 1043 (1999).

${ }^{168}$ Larry Lowenstein \& Jeanne DesBrisay, Liability of Health Care Ethics Consultants, in The Heal.th CaRe ETHics Consultant 133, 148 (Francoise E. Baylis ed., 1991). 
conclusions and recommendations were reasonably warranted,"164 she will probably not be found to have breached her duty to the patient.

If there comes a time when the standard of care includes the ethicist's not issuing a recommendation (because recommendations are considered too influential) ${ }^{165}$ issuance of a recommendation could be considered a breach of the ethicist's duty. The standard of care that would likely be prescribed by a court today, however, could potentially be satisfied (or not satisfied) by a clinical ethicist who performed a consultation in any of the four discussed formats. ${ }^{166}$

\section{Harm}

Harm is usually the most straightforward element of negligence in medical cases. ${ }^{167}$ However, since harm is completely case specific, it is difficult to discuss in an abstract manner. Additionally, even in cases where determination of harm is complicated, it is not affected by the fact that a clinical ethicist participated in the decision-making process. Clearly, then, harm is also not affected by the format of ethics consultation the ethicist employed. For the foregoing reasons, harm will not be discussed further in this Comment.

\section{Causation}

Causation of the harm, on the other hand, is probably the most complicated element to prove in a case involving a clinical ethicist case consultation. In order to be found liable, the defendant's negligence must have been the actual and proximate cause of the harm. "Proximate cause" is defined as "[a] cause that directly produces an event and without which the event would not have occurred." ${ }^{168}$ Unlike the other three, previously discussed elements required for a find-

\footnotetext{
${ }^{164}$ RosS ET AL., supra note 3, at 141.

165 See infra Part IV.B.4.b (discussing how influential an ethicist's "nonbinding" recommendation may be).

${ }_{166}$ See supra Part I.B (delineating four possible formats for an ethics consultation).

${ }^{167}$ One could ask, however, should the law recognize ethical harm? For instance, if there was a situation in which a patient changed her mind about undergoing a procedure, and then learned that the procedure was not medically necessary, could that patient successfully sue on the basis of "ethical harm," even if there was no physical harm? Chances are, what might be considered "ethical harm" would probably be considered when calculating mental and emotional harm.

${ }^{168}$ BLACK'S LAW DICTIONARY 87 (pocket ed. 1996).
} 
ing of negligence, the analysis of causation does differ depending on the format of ethics consultation employed by the ethicist. ${ }^{169}$

\section{a. Ethicist issuing binding decision}

Assuming it is proved that the patient's harm resulted from the medical procedure, the binding decision of a clinical ethicist would clearly be the actual and proximate cause of the harm that resulted.

\section{b. Ethicist issuing nonbinding recommendation}

At first glance, it might seem unlikely that a recommendation by an ethics consultant could be considered the proximate cause of any harm suffered by a patient because of the presence of an intervening, free-willing actor. In other words, since the physician and/or the patient makes the final decision with no duty to follow the recommendation of the clinical ethicist, the clinical ethicist should not be considered the proximate cause of the harm. Society has always expected physicians to take responsibility for the final treatment decisions, despite any outside pressures from institutions, insurance companies, HMOs, or ethics committees. ${ }^{170}$

Some argue, however, that it would be plausible for a court to find that the clinical ethicist speaks with such compelling authority that her recommendation "may place such a heavy burden on those who consult them to follow [her] advice or to come up with very good reasons why those recommendations should not be followed," that those seeking consultation may realistically have no choice at all. ${ }^{171}$ After all, a physician or patient will not approach a clinical ethicist if she does not trust the ethicist's skills and experience in dealing with matters similar to the one at hand (unless the physician is mandated to do so in this instance by the institution, either because of institutional policy or a patient request). ${ }^{172}$ Hence, it should be expected that the physician or patient would treat the "nonbinding" recommendation of the clinical ethicist as, "if not binding, at least highly persuasive, in much

${ }_{1109}$ See supra Part I.B (delineating four possible formats for an ethics consultation).

${ }^{170}$ Fleetwood \& Unger, supra note 15, at 323.

171 ROSS ET AL., supra note 3, at 135; see also George Agich, Authority in Ethics Consultation, 23 J.L. MED. \& ETHICS 273, 275 (1995) (arguing that because ethics consultants are perceived as having authority their recommendations have "a practical effect akin to power").

172 Duval, supra note 143 , at 276. 
the same way as a medical consult." ${ }^{173}$ One reason for this might be that if a patient and her family feel like they are receiving a "fair hearing" for the first time in the medical experience, they may be so grateful that their opinions are finally being considered that they may be unable to think clearly for themselves. ${ }^{174}$ This is equally true when a physician is enmeshed in a complex case because, as George Agich points out, "involvement by the ethics consultant who confirms the difficult nature of the case might lead to effacement of the physician's own independent critical judgment." ${ }^{175}$

Unfortunately, it is often impossible to know what the physician and patient would have done had they not consulted the ethicist or, more importantly, if the recommendation had been other than what it was. In other words, it is difficult to discern whether the ethicist's recommendation was actually a "but for" or proximate cause of the final decision and, hence, the harm. However, considering the facts that many physicians perceive clinical ethicists as encroaching on their decision-making authority, ${ }^{176}$ and patients are sometimes reluctant to trust a "specialist" with whom they have no prior history, it seems pretty clear that the physician or patient would not consult a clinical ethicist if the ethicist's views were not expected to play a significant role in the treatment decision. Therefore, it could be inferred from the mere fact that the ethicist was consulted that her recommendation influenced the final decision and hence was a proximate cause of the harm.

Some argue that in addition to the superior moral authority the clinical ethicist appears to have over the physician and patient, there are institutional factors that contribute to the physician's feeling an obligation to follow the recommendation of the clinical ethicist. As Laurence McCullough writes, "Power is gathering to ethics consultants as a result of growing organizational sanction . ...."177 Merritt explains this point further, writing, "Because the ethics [consultation] is estab-

173 Id; see also BOWEN HOSFORD, BIOETHICS COMMITTEES: THE HEALTH CARE PROVIDER's GUIDE 94 (1986) ("It is inescapable that a bioethics committee will influence physicians' decisions, however. ... Though they ordinarily ... do not write recommendations on patients' charts, their comments will be influential.").

${ }^{174}$ Agich, supra note 171 , at 275.

175 Id

${ }^{176}$ See HOSFORD, supra note 173 , at 93 (quoting a philosopher who serves on three bioethics committees, who says: "We spend a lot of time reassuring physicians that the committee is not in there to tread on their turf-to intrude on their decision-making authority." ").

177 McCullough, supra note 143 , at 56. 
lished as a formal structure for guiding the decision-making process, it would be difficult to argue that the [ethicist's] advice is not a substantial factor in the ultimate determination of a doctor to follow that advice." 178 In fact, the clinical ethicist may be viewed as the "conscience of the institution." ${ }^{179}$ This idea may be due, in part, to the famous In re Quinlan decision. ${ }^{180}$

In Quinlan, the New Jersey Supreme Court ruled that:

If [the hospital ethics committee] agrees that there is no reasonable possibility of [the patient's] ever emerging from her present comatose condition ... the present life-support system may be withdrawn and said action shall be without any civil or criminal liability, therefor, on the part of any participant, whether guardian, physician, hospital or others. ${ }^{18}$

In other words, "compliance with the recommendation of the 'ethics committee' shielded the health care professionals and the hospital from liability." ${ }^{182}$ Since Quinlan, many cases have forced the courts to consider the recommendations of clinical ethicists, ${ }^{189}$ and the authority accorded to these recommendations has varied considerably. ${ }^{184}$ But since none of these cases has been as well known as Quinlan, physicians may not be aware that courts do not consistently consider clinical ethicists to be the "conscience of society." $18{ }^{\circ}$

In sum, the apparent support from the courts and the institution for the clinical ethicist's recommendation, as well as the decision maker's personal feeling that she has inferior moral authority, could

${ }^{178}$ Merritt, supra note 3, at 1275.

179 ROSS ET AL., supra note 3, at 135.

355 A.2d 647 (N.J. 1976).

181 Id. at 672 .

${ }^{182}$ Fleetwood \& Unger, supra note 15 , at 322.

${ }^{183}$ See, e.g., In re L.H.R., 321 S.E.2d 716, 723 (Ga. 1984) (holding that an ethics committee could, but need not be consulted in the present circumstances, since the state had no compelling interest in maintaining the life of a terminally ill infant); Superintendent of Belchertown v. Saikewicz, 370 N.E.2d 417, 434 (Mass. 1977) (rejecting "the approach adopted by the New Jersey Supreme Court in the Quinlan case of entrusting the decision whether to continue artificial life support to the patient's guardian, family, attending doctors, and hospital 'ethics committee'"); In re Torres, 357 N.W.2d 332, 336-37 (Minn. 1984) (using the reports of hospital ethics committees as evidence to evaluate the validity of the decision to remove life.support); see also Fleetwood \& Unger, supra note 15, at 322 (discussing these three cases).

${ }^{184}$ See Fleetwood \& Unger, supra note 15, at 322 (discussing In re L.H.R., In re Torres, and Saikewicz, and the different levels of authority accorded to the ethics committee recommendations in those cases).

${ }^{185}$ This point is exemplified by the common misconception that "[p] hysicians are in less legal danger when they consult bioethics committee members than when they make decisions privately." HOSFORD, supra note 173 , at 88. 
lead a physician or patient to feel that she has no choice but to follow the "nonbinding" recommendation of the clinical ethicist. If a court were to accept this argument, the causal link between the clinical ethicist's "nonbinding" recommendation and the harm to the patient would be established.

\section{c. Ethicist issuing nonbinding recommendation, but convincing the parties to accept her proposal}

If it is possible for a clinical ethicist who simply issues a nonbinding recommendation to be considered the actual and proximate cause of the harm, as I argue above, then a clinical ethicist who goes one step further and convinces the parties to accept her proposal could clearly be found to be the actual and proximate cause of the harm; the plaintiff's argument that the ultimate decision would have been different had it not been for the actions of the clinical ethicist is stronger when the ethicist actively attempts to persuade either the patient or the physician. ${ }^{186}$

\section{d. Ethicist facilitating consensus, with no recommendation}

As difficult as proving causation is when the ethicist issues a recommendation, it is considerably harder when the ethicist does not issue a recommendation, but rather simply facilitates a consensus between the parties involved. In order for causation to be found, the failure of the ethicist to adequately perform the consultation task (i.e., no consensus was reached) would have to result in the implementation of an ethically impermissible option, which then caused harm to the patient. If the option was ethically permissible, though medically incorrect in those circumstances, the ethicist's actions (or inaction, as it may be) could not be considered a cause because she is not a medical expert. The ethicist's only goal in consultation is to ensure that the decision reached is ethically appropriate. ${ }^{187}$ Hence, only if an ethicist allows an ethically impermissible outcome to the consultation, which causes harm to the patient, can the ethicist's actions be considered a legal cause of the harm. For such an instance to arise, the clinical ethicist would have to be grossly negligent-an extremely unlikely but not impossible occurrence.

${ }^{186}$ See supra Part IV.A.3.b-c (discussing possible intentional tort liability for ethicists issuing nonbinding recommendations).

${ }^{187}$ See Casarett et al., supra note 30, at 8-9 (arguing that "[ $\left.t\right]$ he challenge for the ethics consultant is to determine when ... a conclusion has moral validity"). 
C. What Should Be a Clinical Ethicist's Role in Case Consultations if She Wants to.Limit Exposure to Liability?

It is clear from the discussion concerning potential, theoretical liability for clinical ethicists involved in case consultations that ethics consultants who refrain from issuing recommendations are significantly less likely to be held liable for harm to a patient that may subsequently result. Therefore, if clinical ethicists want to reduce their exposure to potential liability, they should adhere to the "soft" model of consultation and avoid making recommendations. ${ }^{188}$ This is not to say that the ethicist should be a passive participant in the consultation process. Rather, she should actively guide the discussion, ensuring (1) that the patient and physician are both given the opportunity to explain their respective positions, and (2) that issues crucial for an acceptable outcome, yet previously unidentified by the participants, are raised and adequately discussed. The ethicist should also exclude clearly unethical options, thereby guaranteeing that all options are ethically permissible. If the ethicist is asked for a recommendation and she feels that it would be appropriate in that particular instance to issue one, she "should indicate that ... her personal preference may reflect a bias." However, she should be aware that doing so could make her more vulnerable to a civil action brought against her.

\section{CONCLUSION}

Unless society's views about morality, paternalism, and patient autonomy change and society becomes less litigious, clinical ethicists who participate in case consultations need to worry about the fact that they could potentially be held legally liable for the role they play in

${ }^{188}$ It is extremely important to understand that I do not claim that the "soft" model will ensure the best results either for individual patients or for society as a whole. Rather, I suggest that clinical ethicists should use the "soft" model of consultation if they want to reduce their exposure to potential liability.

${ }^{189}$ Howe, supra note 107 , at 146 . Howe goes on to explain that "[b]y qualifying the validity of this ethical opinion, the ethics consultant . . stays within his or her expertise and is likely to further the credibility of the consultant role." Id.; see also Ackerman, supra note 16, at 47 ("Recommendations by the ethics consultant are not ruled out, but the consulting ethicist must clearly convey the status of the recommendation. It is not an assertion that a particular course of action has been independently determined to be the morally correct option."); James F. Drane, Hiring a Hospital Ethicist, in ETHICS CONSULTATION IN HEALTH CARE, supra.note 16, at 117, 122 ("[T] here will certainly be situations in which the ethicist advocates one opinion over another, but he or she should only perform this service when asked and should do so without appearing to take charge of decision making or assuming an air of infallibility."). 
case consultations. Clinical ethicists are not helpless, though. Rather, there are many steps they can take that will protect them from being placed in such a situation, including listening to the concerns of the patients and physicians and attempting to build consensus between the opposing views, and not offering recommendations. It is not easy to predict what effect the first finding of liability of a clinical ethicist will have on society, but it is likely that there will be both positive and negative consequences. My prediction is that a clinical ethicist will be found liable in the near future, but there will be neither an explosion of litigation nor a significant alteration of the clinical ethicist's role in case consultation, as expected-at least, as long as clinical ethicists learn about the realistic risks of liability and how to avoid them without sacrificing the beneficence of having ethics consultations. 
* $* * * * * *$ 